laryngitis; another French term for it being "laryngite striduleuse"-stridulous laryngitis-while spasmodic croup is designated by them, as by us, "laryngismus stridulus," or "thymic asthma."

There can be no question that simple inflammatory croup, or catarrhal laryngitis, the "false croup" of the French pathologists, is as distinct from the purely spasmodic croup as it is from diphtheritic or true membranous croup.

I am, Sir, your obedient servant,

Svaile-row, April 26, 1875. George Johnson.

\section{"CROWNER'S QUEST LAW" IN GERMANY.} To the Editor of THE LANCET.

SIR,-Your readers will perhaps be interested to hear that the Medical Association (Genossenschaft der Arzte) of Dresden has just issued a petition, signed by Dr. Küchenmeister (the well-known helminthologist), and addressed to the "Imperial Commission of Law at Berlin," eventually to the Reichstag, in which the profession requests the Government to institute the "compulsory dead bodies' inquest after the model of the English coroner system." It is really astonishing that the Government should not have thought it necessary to give in the new penal code of the German Empire a regulation for so important a proceeding as the statement of death is considered to be by all civilised nations; the more so as several of the minor States of Germany have hitherto been enjoying the beneficial influence of one or other modification of the coroner system.

Another point in the new code to which the Genossenschaft objects very energetically is that in criminal case the Government does not oblige the judge to take any notice of the sentence of the medical man, but leaves it entirely to the bon plaisir of the judge to do so or not. Dr. Küchenmeister shows, in a very elaborate historical sketch which is subjoined to the petition, that even in old times the opinion of the medical man in criminal cases was of the greatest influence, and that, with regard to the high standard of the medical science of our days, we are entitled to have a decisive vote in foro.

Most likely the petition of the Dresden Genossenschaft will be adopted by all medical societies of Germany, and it is to be expected that the Government will comply with the desire of the profession.

Hoping that you may find the subject of my letter worthy of your attention,

Dresden, April 22nd, 1875.

I remain, Sir, yours obediently, R. H. Pierson, M.D.

\section{SKETCHES OF CONTINENTAL HOSPITALS.} (By our Special Correspondent.)

$$
\text { VII.-VIENNA. }
$$

(Concluded from page 215.)

THE clinical work of the Allgemeine Krankenhaus begins at 8 A.M., and one of the earliest to lecture is Prof. Hebra. His clinique is large and always well attended, the fee for each session being one sovereign. In his wards burns and scalds, small-pox and other of the exanthemata are treated, in addition to almost every variety of skin disease proper. Not much instruction, however, is imparted at the bedside, but a number of selected cases are brought into the theatre, stripped, and either laid on a bed or placed in a circular movable chair in the centre of the square arena, where the professor and his assistants stand, and then a demonstration of the case is made. Hebra's stiyle of lecturing is conversational, and at times jocular stories and witty remarks are interspersed with the more serious subjects of his discourse. Around the walls are models and drawings of the rarer cutaneous affections, which are from time to time referred to, but in the main the teaching is founded on the practical treatment of the vast crowd of in- and out-patients who are daily seen by the professor or his assistants. Dirt, and the bites of various insects, are a fruitful source of skin disease, particularly among the poorer Polish Jews, whose habits and dress are the reverse of cleanly; hence soft-soap is freely recommended. Eczema is treated as a purely local affection; unguentum diachyli, which is a combination of litharge, resin, soap, and oil, is frequently ordered for it, and then follows either the huile de Cade, tar ointment, or what Hebra, out of respect for a great English dermatologist, calls the unguentum Wilsonii, or benzoated zinc ointment. Brandy-and-water lotion is applied to relieve irritation in lepra and psoriasis, and arsenic is given internally, either in the form of solution of arseniated potass or in pill, one-tenth of a grain of white arsenic being thus given three times a day for a long period, and the remedy pushed until in some cases as many as 5000 pills have been taken. Lupus is treated by the application of the solid nitrate of silver and the internal administration of cod-liver oil. Baths, of which there are every kind in the hospital, are much ordered, and also various mineral waters, Carlsbad, from its aperient and cholagogue properties, being greatly in favour.

Billroth has the largest surgical class, and it includes many representatives of Russia, Italy, and America, also not a few from England and other countries. At 9.30 A.Jr. his theatre, a small place, barely large enough for his class, is filled, and rapidly are cases brought in (if necessary on their beds), examined, diagnosed, and, if their cases require it, operated on. One day a number of cases of nævus were brought forward. The pathology of the disease having been explained, Professor Billroth proceeded to operate. In four cases he passed several thin cotton threads, saturated with a solution of perchloride of iron, through the nævi, and after allowing them to remain four or five days he found great consolidation had taken place. A child aged ten, with nærus of the tongue and left side of the cheek, was also shown, who had been treated successfully by repeated punctures with the galvano-cautery. The good effects of the same apparatus were seen in a case of central epithelioma of the tongue of an old man. With one wire of the galvanocaustic écraseur the base of that organ is severed in a minute and three-quarters, and with another the circumference in two minutes and a half, and there is absolutely no bæmorrhage. Plastic operations are frequent; one frightfullooking woman, with syphilitic destruction of the face, presented berself to have the left lower eyelid restored; on a previous occasion Billroth had made her a new lower lip, and he proposed afterwards to furnish her with a new nose. Esmarch's bandage is in constant use, and one novel application of it was for syncope the result of hæmorrhage, both legs and thighs being rapidly bandaged, so as to drive more blood from the lower extremities to the heart, and so excite its action. Hydrocele of infants is treated by passing a thread through the tunica vaginalis. Pachyderma of the scalp, a disease common in Styria and Istria, characterised by great thickening and induration of the skin, is treated by the removal of elliptical sections of both the skin and subjacent tissues. Resections are all performed subperiosteally, and all except those of the hip seem to do well. In a case of phosphorus necrosis of the lower jaw, the whole of that bone had been taken away subperiosteally, and a new jaw was in course of formation. Lymphoma of the neck seems more common than with us, and the treatment consists in the injection either of one drop each day of solution of arseniated potass or the same quantity of a solution of chromic acid, one grain to a drachm. Another disease of debility, rachitis, is very frequent, and is treated by forcible straightening, or even fracture, of the bones of the leg, and then the application of splints. Wounds are left open ; thus in a case of Syme's amputation at the ankle, which did well, Billroth simply had a drainage-tube passed from side to side, and the stump left perfectly uncovered. Sometimes he applies glycerine to wounds, but Lister's plan is not seen in his wards

Professor Dumreicher has a theatre, which is larger and more commodious, adjoining that of Billroth. He is a great authority on military surgery, and is a good clinical teacher. His manner is sharper and not so attractive as that of his great surgical colleague, and his clinique is smaller. In Professor Dittel's wards are seen many cases of urinary disease-a subject on which he has written well. For strieture he uses a catheter which tapers to a point. Here also may be seen the elastic ligature as applied by the author of the practice in the treatment of hæmorrhoids, prolapsus ani, \&c. One of the great advantages of the large Vienna Hospital is that all the specialities may be 